\title{
Designing Enterprise Architecture toward Big Data readiness using TOGAF ADM in the public health sector
}

\author{
Agung Laksono ${ }^{1}$, Gunawan Wang ${ }^{2}$ \\ ${ }^{1}$ Bina Nusantara University, Indonesia, agung.laksono@binus.ac.id \\ ${ }^{2}$ Bina Nusantara University, Indonesia, gwang@ binus.edu
}

Received Date : January 04, 2022 Accepted Date : January 30, 2022 Published Date : February 07, 2022

\begin{abstract}
In the pandemic Covid-19, public health sector is the key for managing national health care. According to Ministry of health $(\mathrm{MoH})$ data, there are 9.993 public health service institution (puskesmas) that spread across Indonesia district level. In this study, we focus on puskesmas as the representative of Ministry of health $(\mathrm{MoH})$. Most of the operations and data taken from the public health center such as patients data, health record data, pharmacies data, and more. The Ministry of Health is responsible for many sectors such as health and drug regulation, health service and equipment, illness, pandemic management, health institution, and so on. Responding to numerous roles above, Information Technology is mandatory for all division in the $\mathrm{MoH}$. However, there are hundreds silo applications has been developed in the Ministry of health. As the consequence, puskesmas should operate many applications.
\end{abstract}

In this study, we conduct an empirical study to design an enterprise architecture on data integration and big data using real cases in the Ministry of health. TOGAF ADM Version 9.2 is used to unearth current condition and set the vision that measures the readiness for implementing Big Data technology. We conduct interviews with management and technical staff to analyze the issues and desirable state, and then conduct gap analysis. Our study provides a systematic transformation for big data analytics in public health services to increase competitive advantage in the public health sector. Furthermore, the challenges are hundreds of applications has been running, lack of regulations, and an information technology roadmap, and the absence of software documentation. Our study defines the data mart architecture as a proposal for implementing big data as an interoperability tool to generate a consistent data. Data regulation and standard protocol must be defined clearly.

Key words : TOGAF, big data, IT Strategy, Public health.

\section{INTRODUCTION}

This study conduct a deep analysis in designing Enterprise Architecture toward Big Data Architecture readiness for public health sectors of Indonesia. It begin with the architecture vision, review technical documents, study related regulation, analyze current IT strategy and future IT strategy. TOGAF framework is adopted to break down the complexity of current business model and existing applications then recreate a new model that suitable to implement big data.

The Ministry of health has numerous variety of stakeholders and business processes. They are responsible for managing health research and development, health financing, human health resources, pharmaceutical preparations, medical devices and food, health management, community development, information, and heath regulation in Indonesia. Therefore information technology is needed in each sector of services. Even though the Ministry of Health had attempted to create Information Technology planning and regulation in 2012-2014 [1] and 2015-2019 period [2], the result was insignificant. Application flourishes exponentially and independently in each department. It happens because there's no standard protocol, coordination, and synergy among the sub-departments together to gather the data and information. As a result, applications develop and running well inside the Ministry of health ecosystem but have not been integrated.

In the current situation, Enterprise architecture is needed by the Ministry of health to make sure the data orchestration from hundreds of applications can be integrated, reliable, and consistent. Niemi claimed that EA helps manage the complex business process, pinpoint the goal by showing the current state and ideal state, and connect it by conducting gap analysis[3].

\section{RELATED WORK}

Before further discussion in analyzing public health sector, a prior studies regarding TOGAF has been reviewed. In this divided into 3 TOGAF implementation areas, which are strategic planning, business improvement, and adopt new technologies. 
Agung Laksono et al., International Journal of Emerging Trends in Engineering Research, 10(2), February 2022, 114 - 122

\subsection{TOGAF for strategic planning}

TOGAF ADM is widely implemented in several strategic areas, especially in government. A study that focuses in information system strategic plan in the central of data and information department at Minister of agriculture shows evidence that many silo application development should be integrated to extract the information and decrease the complexity. TOGAF ADM successfully provides a helicopter view of the current situation and initiates strategies to integrate and increase the public services[4]. Another related study in the government area, TOGAF ADM, was also implemented at Indonesia Archive Institution (ANRI) to create an Information technology roadmap for the next five years[5].

Another implementation of TOGAF adopts to automate a business process. A case study conducted at an Information Technology company in Indonesia shows that TOGAF ADM helps organizations aligning their information technology and business. The organization can see the urgency and benefit of implementing service-oriented applications (SOA) to integrate among their applications. The study also shows that TOGAF ADM helps management find several business processes that are not yet covered by the current information system[6].

IT Strategic plan also implemented in an Iranian hospital, the study compares Enterprise Architecture Framework and chooses TOGAF ADM as their tool in this study. The study provides a new Hospital Architecture Modelling based on TOGAF ADM that has been customized at eight levels and 11 parts. The result shows that the Iranian only implement several phases of TOGAF ADM, such as Architecture vision, business architecture, information system architecture, and information technology architecture[7].

\subsection{TOGAF for business improvement}

TOGAF ADM is widely implemented in the health care area to improve the business by measuring current processes to understand the overall business and find new insights. In a case in Dharmais Hospital, TOGAF ADM is used to develop users' sense of belonging, Information technology awareness and increase the user knowledge in IT usage[8]. The research shows 36 findings that can be improved from the Dharmais hospital in the wide-area such as sales and marketing activities, education and training activities, Cancer registration activities, and research activities. Based on the finding, this study provides seven recommendations for ownership of business users, five recommendations to align business and Information technology strategies, 16 recommendations to increase competitive advantage through information technology, and eight recommendations in optimizing IT operation.

\subsection{TOGAF for adopting new technologies}

TOGAF helps management in a energy company to adopt a new technology [9]. The study focus on designing Enterprise Architecture inside the gasoline distribution system. The system manages the gasoline from the production house to their merchants. It also helps the company to increase the production efficiency by monitor the distribution pipeline and calculate the merchant stock. The author focuses on three areas of enterprise architecture, which are (1) business architecture, (2) Information System Architecture, and (3) information technology architecture. This study shows that TOGAF ADM is a powerful tool to unveil improvement that can be used in sales productivities and customer loyalty [9]. Florian has conducted another study in the banking area. The author implements TOGAF ADM to transform conventional and manual activities to systematical management using information technology by designing Digital Loan System. The study provides a comprehensive analysis by providing Stakeholder power and interest matrix, value chain diagram, RACI Chart, business flow diagram for current and targeting system, benefit and effort matrix, IT roadmap, and the prototypes of the system. The study shows that TOGAF could help the organization optimize the cost, prioritize the Information Technology projects, open up new opportunities, automate the verification and analysis, and increase the accuracy in choosing potential customers[10].

\section{RESEARCH FRAMEWORK}

The study using a qualitative method by conducting interviews and literature review. The interviews were conducted with the top management, IT staff, and public health operators. Moreover, this study's supported by literature reviews such as regulation, software documentation, manual guide, IT plan. Thus documentation becoming the primary material in this research.

To make the study more powerful, we adopt the Open Group Architecture Technique (TOGAF) framework as a guideline to maintain systematic, relevant, and precise while doing analysis. Our reason for using TOGAF Architecture Development Method (ADM) version 9.2, besides the advanced version of TOGAF, is the systematical and error correction compared to the previous version[11].

\section{Phase 1. Problem Identification}

Problem Identification is conducted through interviews and discussion with main stakeholders from the Ministry of health: Information System Coordinator, Information Technology Coordinator, Digital Transformation Strategy Consultant. 


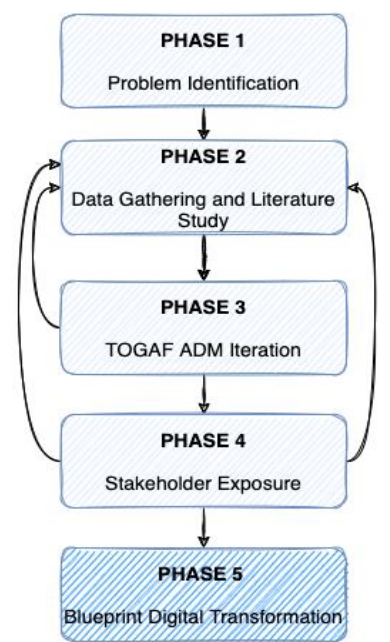

Figure 1. National Medium Term Development Plan of MoH

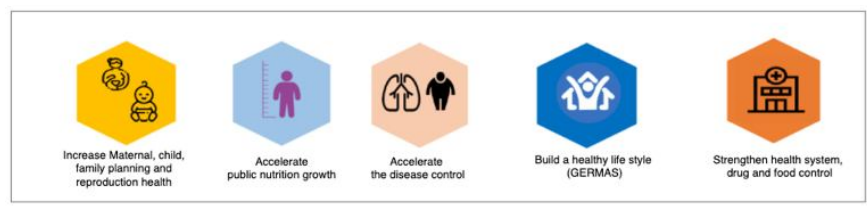

Figure 2. Research framework

\section{Phase 2. Data Gathering and Literature Study}

Data and information sources consist of primary and secondary sources. Primary sources are gathered from interviews and discussions by executive management. Secondary sources are collected from reports, regulations, benchmarking studies, manual guides, system documentation. Ultimately, a literature study is used to adopt industry 4.0 components as the architecture vision of enterprise architecture. All data above is used to create a model, design targeted architecture, and evaluate the gap analysis from each TOGAF ADM iteration.

\section{Phase 3. TOGAF ADM Iteration}

This phase is a crucial part of this study. All steps in this phase will expose the current condition of the public health service area that is managed by IT DEPARTMENT (center of data and information department) Ministry of Health. Each step in this phase correlates with each other and should be executed consecutively. Below is the information from each step: Preliminary, Architecture Vision, Business Architecture, Information system Architecture, Technology Architecture, Opportunity and Solution.

\section{Phase 4. Stakeholder Exposure}

Stakeholder Exposure is a presentation and discussion to the Ministry of Health stakeholder to confirm and evaluate the design, findings, and architecture vision. In this phase, a study could be iterate to the previous phase to enrich blueprint enterprise architecture results.

\section{Phase 5. Blueprint Digital Transformation}

Blueprint Digital Transformation is a complete documentation of business architecture, information system architecture, and technology architecture that will be used as a proposal or suggestion to the Ministry of Health to optimize the public health service system.

\section{RESULT AND DISCUSSION}

In this section, The data will be provided to unearth current condition of public health services in puskesmas, then measure the gap between current and desirable state. Moreover, the analysis is classified into phases referring TOGAF ADM guideline.

\subsection{Preliminary Phase}

This phase focuses on defining the purpose of enterprise architecture that will be asses and design. The study collect the data and information from the IT division perspectives in Ministry of Health. The interview conducted to the head of information system, head of infrastructure, and coordinator of data standardization. The conclusion of this interview are few targets that must be added in the new enterprise architecture in public health service system, which are:

\section{A. Business aspect}

A desirable business aspect should fulfill these criteria: (1) Single identity health record, (2) decision support system based on valid data, (3) integration services among governments, health institutions, and health industries.

\section{B. Data aspect}

A massive data sources should be able to provide a useful information. Moreover, it must be easy to access and reliable. Below are the criteria of future data in public health service: (1) Data integrity, (2) interoperability data, (3) data security, (4) data authority, (5) data accuracy.

\section{Application aspect}

A valid data comes from a strong application. Since the application is a part the interact with the human, it should has a (1) user-friendly interfaces, (2) able to serve in remote areas, (3) microservice architecture, (4) able to integrate.

\section{Technology aspect}

As the foundation of information technology, infrastructure should be able serve in 24 hours / day and 7 days / week. In the other word, the technology must merit these 3 criteria: (1) Availability, (2) reliability, (3) integrity.

\subsection{Architecture Vision}

The vision of this architecture architect must align to the national plan. Figure 2 shows a National Medium Development Plan from $\mathrm{MoH}$ pillars that becoming a focus development in Minister of Health in 2020 to 2024. In 
addition, this studi also do deep analysis from previous information and documents, 2015 to 2019 enterprise architecture, public health service regulation [12] and public health service information system regulation[13].

Breakdown the strategy into vision, mission, and operation is a broad topic of discission. In our study, the main investigation are identifying components for implementing Big Data Analytics in each key areas. Figure 3 shows a Value Chain diagram that created to shows main and secondary activities that exist in public health service. By seeing this diagram, it can also unveil potentials value that can be added to implement big data analytics in public health service.

Our work contribution is related to the fifth target of MoH. In order to support this ideas, $\mathrm{MoH}$ create a Digital Transformation Officer team that calls DTO. DTO develop and strategic plan, execution schema and take care of the implementation of information technology. Moreover, DTO team also provide step-by-step digital transformation in health service and regulation that shows in table 1 .
Figure 3 shows the value chain of public health service activities. Inbound activities list consist of all activities related to receiving and distribute input activities such as medical records, registration process, drug storage and circulation, and cashier. Furthermore, Operations provides various activities to serve directly to the patients or public, as explained in the Ministry of health regulation number 31 in 2019 [12].

After analyzing the value chain of public health service, the components that interact inside it have been seen. Our finding shows that 77 applications are used at public health services, and some input the same data, such as patient biodata. In the next step, interviews were conducted to confirm those components and enrich the information regarding the challenges in managing the public health service system. Several challenges have been collected on the interview, as the list below.

Infrastructure: Cloud Service,
Human Resources Manage
Technology Development: Int
Procurement: Medical Equi
Inbound Activity
1. Patient management
2. Drug Management
3. Medical Record
4. Cashier

Internet provider

formation System, Mobile System, IT Operation

ent, Pharmacy, Information Technology hardware, assets

Operations Outbound Activity

1. Health Service

2. Polyclinic Service

3. Laboratory Service

4. Health Promotion
Medical Referral letter

2. Activity report

3. Financial Report

4. Health insurance

5. doctor's orescriotion
1. Disemination

2. Social Media

3. Health Network

Figure 3. Value Chain Diagram

Table 1. Health Digitalization Priority Strategic

\begin{tabular}{|c|c|c|}
\hline Focus Activities & Key Performance & Outcome \\
\hline $\begin{array}{l}\text { 1. Integration and develop a } \\
\text { health database system }\end{array}$ & $\begin{array}{l}\text { 1. Single National } \\
\text { health data } \\
\text { 2. Health data system } \\
\text { integration } \\
\text { 3. Develop Health } \\
\text { system Big Data } \\
\text { Analytic }\end{array}$ & $\begin{array}{l}\text { Increase decision } \\
\text { support system } \\
\text { based on accurate } \\
\text { data }\end{array}$ \\
\hline $\begin{array}{l}\text { 2. Integration and develop a } \\
\text { health service system }\end{array}$ & $\begin{array}{l}\text { 1. Health System } \\
\text { Integration } \\
\text { 2. Business process } \\
\text { Integration } \\
\text { 3. Increase human } \\
\text { skills } \\
\text { 4. Health system } \\
\text { helpdesk }\end{array}$ & $\begin{array}{l}\text { Increase the } \\
\text { efficiency of the } \\
\text { public health service } \\
\text { in public health, } \\
\text { clinic, hospital, } \\
\text { laboratory, and } \\
\text { pharmacy }\end{array}$ \\
\hline $\begin{array}{l}\text { 3. Develop a Health } \\
\text { technology ecosystem }\end{array}$ & $\begin{array}{l}\text { 1. The } \\
\text { implementation of } \\
\text { telemedicine } \\
\text { 2. Develop health } \\
\text { regulatory sandbox } \\
\text { using industry } 4.0 \\
\text { approach }\end{array}$ & $\begin{array}{c}\text { Create collaboration } \\
\text { and health } \\
\text { ecosystem among } \\
\text { government, } \\
\text { industries, and } \\
\text { society }\end{array}$ \\
\hline
\end{tabular}

A. Multiple Entry data

In total, 77 applications operated at puskesmas, some of the applications input the same entity. On the other hand, data integrity and interoperability should be taking a role in this condition.

B. Lack of Report format

The current system is unable to provide a standard report. Moreover, the system only covers the district level. Hence, the district operator should process the data and send it to the Ministry of health using another application. It isn't efficient.

C. Unable to integrate

Many information system variants that used by each public health service. Each application has its identification numbers and code references; hence hard to integrate. The System standardization coordinator division at IT department has built a taxonomy as a reference code. Hence, the future system should provide a standard reference code for all references such as health service code, drugs code, and so on.

\subsection{Business Architecture}

This phase will discuss information technology from a business perspective. The study begins with the organization structure, current state, and the desired business architecture. Based on regulation, the Public health service must coordinate directly with the district public health office to report the activities and programs, then vertically reported to 
the province public health office and lastly to the Ministry of Health[13]. Moreover, implementing technology could cut the hierarchy; hence, the data could be stored on one server and report data based on each authority. On the other hand, the current Public Health Information System could not cover the whole process. The system is only able to reach the district public health level. Hence in this section, the study discusses the organizational structure of IT department, who manages the public health service system, analyzes the role and responsibilities of the stakeholders by providing a RACI chart diagram, analyzes the current business process and targeted business model.

\subsubsection{Organization Structure}

IT department Ministry of Health manages public health service information system. Figure 4 shows the IT department organization structure. The one responsible for managing the public health service is the application and database unit. However, other units also contributes to managing the system, for instance, the information system standardization unit has a responsibility to manage reference data such as public health identity code, pharmacy, clinic, medical tool, etc. another unit that contributes on this is infrastructure information technology which provides the server, network, storage, etc. Thus, all unit in IT Department having strong relationship as the data contributor and beneficiary.

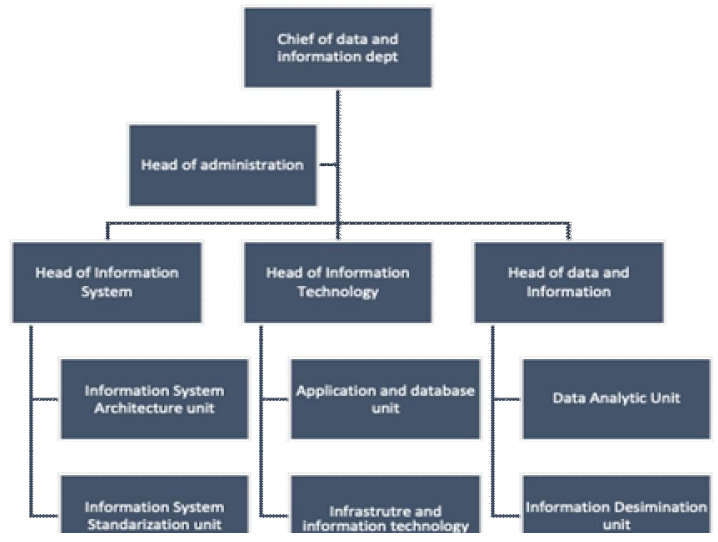

Figure 4. IT Department at $\mathrm{MoH}$

\subsubsection{Business Flow ecosystem in public health service}

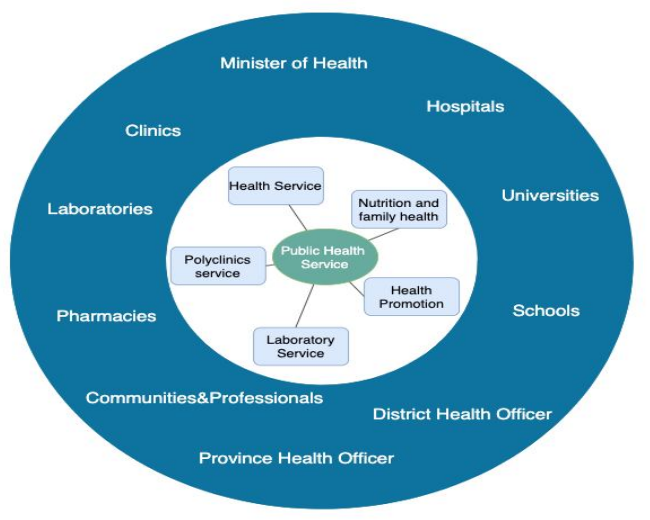

Figure 5. Public health service ecosystem
After knowing the organization structure, our study continue to unearth the business process area in public health service. In our finding, public health service developed in sub-district level almost in each district. There are 9.993 public health services in Indonesia on 2019[14]. Each public health service having different services and organization structure depends on the health regulation implemented in their province, social health condition, total population, financial support of district or province health officer, industries and social life around them.

Public health service is a public health facility that conducts health care to the community and personal at the first stage to prevent and promote healthy life stye around their area. Public health service responsible in many services which inside and outside the building. Table 2 shows the public health service facility.

Table 2. Public health service list

\begin{tabular}{|c|c|c|c|}
\hline No & Service Name & $\begin{array}{l}\text { Activity } \\
\text { Category }\end{array}$ & $\begin{array}{l}\text { Public Health Service } \\
\text { Type }\end{array}$ \\
\hline 1 & $\begin{array}{l}\text { Inpatient health } \\
\text { service }\end{array}$ & $\begin{array}{c}\text { Indoor } \\
\text { Activity }\end{array}$ & Public Health Effort (UKM) \\
\hline 2 & $\begin{array}{l}\text { Outpatient health } \\
\text { Service }\end{array}$ & $\begin{array}{l}\text { Indoor } \\
\text { Activity }\end{array}$ & $\begin{array}{l}\text { Personal Health Effort } \\
\text { (UKP) }\end{array}$ \\
\hline 3 & General Polyclinic & $\begin{array}{l}\text { Indoor } \\
\text { Activity }\end{array}$ & $\begin{array}{l}\text { Personal Health Effort } \\
\text { (UKP) }\end{array}$ \\
\hline 4 & Dental health Care & $\begin{array}{l}\text { Indoor } \\
\text { Activity }\end{array}$ & $\begin{array}{l}\text { Personal Health Effort } \\
\text { (UKP) }\end{array}$ \\
\hline 5 & Medical Record & $\begin{array}{l}\text { Indoor } \\
\text { Activity }\end{array}$ & $\begin{array}{l}\text { Personal Health Effort } \\
\text { (UKP) }\end{array}$ \\
\hline 6 & Family Health service & $\begin{array}{l}\text { Outdoor } \\
\text { activity }\end{array}$ & Public Health Effort (UKM) \\
\hline 7 & Health Promotion & $\begin{array}{l}\text { Outdoor } \\
\text { activity }\end{array}$ & Public Health Effort (UKM) \\
\hline 8 & Environmental Health & $\begin{array}{l}\text { Outdoor } \\
\text { activity }\end{array}$ & Public Health Effort (UKM) \\
\hline 9 & $\mathrm{P} 2 \mathrm{P}$ & $\begin{array}{l}\text { Indoor } \\
\text { Activity }\end{array}$ & $\begin{array}{l}\text { Personal Health Effort } \\
\text { (UKP) }\end{array}$ \\
\hline 10 & $\begin{array}{l}\text { Emergency Unit } \\
\text { service }\end{array}$ & $\begin{array}{l}\text { Indoor } \\
\text { Activity }\end{array}$ & $\begin{array}{l}\text { Personal Health Effort } \\
\text { (UKP) }\end{array}$ \\
\hline 11 & Normal birth & $\begin{array}{l}\text { Indoor } \\
\text { Activity }\end{array}$ & $\begin{array}{l}\text { Personal Health Effort } \\
\text { (UKP) }\end{array}$ \\
\hline 12 & Homecare service & $\begin{array}{l}\text { Outdoor } \\
\text { Activity }\end{array}$ & $\begin{array}{l}\text { Personal Health Effort } \\
\text { (UKP) }\end{array}$ \\
\hline 13 & Pharmacy & $\begin{array}{l}\text { Indoor } \\
\text { Activity }\end{array}$ & Public Health Effort (UKM) \\
\hline 14 & Public health care & $\begin{array}{l}\text { Outdoor } \\
\text { Activity }\end{array}$ & Public Health Effort (UKM) \\
\hline 15 & $\begin{array}{l}\text { Administration and } \\
\text { finance }\end{array}$ & $\begin{array}{c}\text { Indoor } \\
\text { Activity }\end{array}$ & $\begin{array}{l}\text { Personal Health Effort } \\
\text { (UKP) }\end{array}$ \\
\hline
\end{tabular}

Public health institutions serve patients inside the building and conduct outdoor activities such as health promotion, homecare service, coordination with hospitals, clinics, laboratories, pharmacies, schools, campuses, and so on. As a vertical government health service, the public health service is responsible for maintaining the health care network by share new regulations, data, information, and report regarding health status at the sub-district. All information about health status in their area will be reported to the district health office. Figure 5 reveals the ecosystem of public health service among public he, district health service, Ministry of 
Health, and other institutions. There are five primary public health services: health service, polyclinics service, laboratories services, health promotion, nutrition control, and family health care.

Data is becoming the basic need for taking a strategic decision in every level of health institution such as sub-district, district, province, Ministry of health, and other institution like BPJS and insurance company. As a consequence, there is tens application who build their own 'island' and gathering their data by asking public health service to input the data. Applications such as SIGIZI, an application to collect nutrition In the public, SIHA, application for HIV/AIDS, SITB, monitor tuberculosis, SIHEPI for hepatitis, and so on.

\subsubsection{Data flow in public health service}

According to the regulation, in each sub-district at least have one public health institution [13]. Furthermore, a public health principle is pointed by the regent of the district health office, and as a consequence, the public health service should report to the district regularly. Figure 7 shows the information flow from the public health institution to Ministry of health.

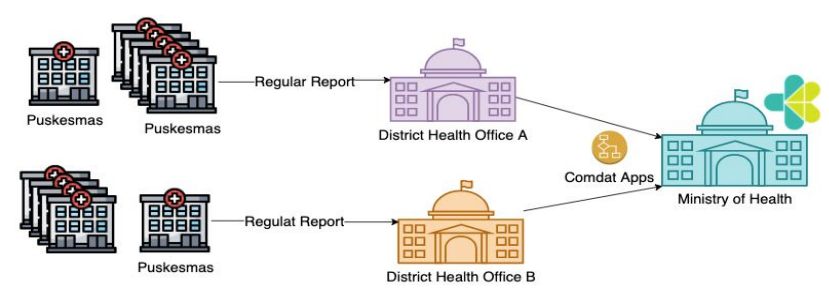

Figure 6. Public health data flow

The data from each public health service should be reported to district level before stored at the Ministry of health or Province health office. Since the data source coming from a system or manual, the consistency and integrity of data might not be very well. Hence, this study will propose a new transformation model to help public health care increase the data quality and consistency.

After defining the ecosystem of public health service, the study concludes that an input system should work only in a single application, and the others should trust the data and use it for a specific purpose. Moreover, the public health service should enlarge the scope and use nationally in IT department in the Ministry of health.

Public Health Apps data input is a single application that covers all processes in Public Health institutions especially input data, reporting, and medical records. The data will be stored in a data warehouse used to serve activities inside and outside the Minister of health.

\subsection{Information System Architecture}

This section provides the analysis of current and desirable information system architecture in public health service.

\subsubsection{Application Architecture}

MoH IT department develops an application to manage the core service, namely Sikda Generik. Sikda generik consist of transactional activities, registration, and cashier, outdoor activity, health care data, reports and management systems. The system is also integrated to district level (see figure 7). The challenge is when a new district registers and willing to use sikda generic, the operator must clone and install sikda generic and deploy to a new virtual server. If all the district in Indonesia willing to implement Sikga Generic, it requires 514 servers running to server 9.993 public health service.

A fact in current condition in public health service, there are 77 applications related to public health service ecosystem. Some of the application (55 apps) require input data, and the rest integrated host to host to other institutions. We could say that most of the applications in public health services are fragmented based on the functionalities and specific domain business. For instance, infectious diseases service involved 11 types of applications which are HIV/AIDS app, captor therapeutics app, malaria app, scarlatina app, measles app, hepatitis app, acute respiratory infection, filariasis. Therefore, those silo applications should be standardized and coordinated only in a single application.

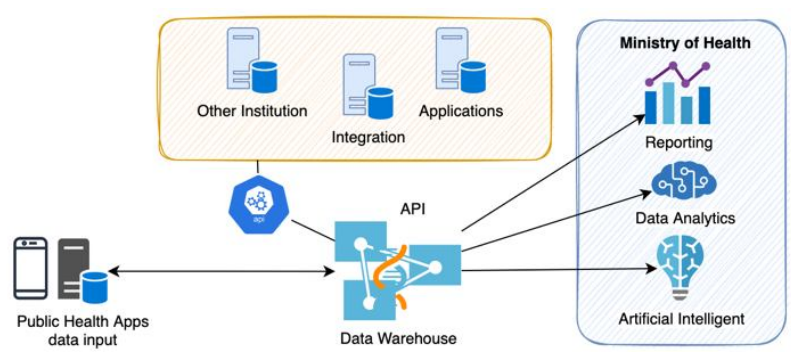

Figure 7. Future application Architecture

Our proposal in facilitating public health service platform for Big Data Readiness calls Sikda New Generation (NG). sikda new generation using modern development approach by providing microservice architecture system. Sikda NG consists of backend and frontend in a modern programming language that supports multicore computing, which can optimize concurrent process execution with multiple core processors' power.

In the front end, Sikda NG will run in mobile and web responsive. The web frontend will use React JS, and for the mobile platform using Flatter framework, a hybrid mobile technology which compatible with android and IoS platforms. Moreover, we also implement offline first technology for the application because the geographic and internet connection 
Agung Laksono et al., International Journal of Emerging Trends in Engineering Research, 10(2), February 2022, 114 - 122

varies among public health services in Indonesia. Hence, the application should be able to run in unstable and offline mode. Whenever it gets the connection, the data automatically synchronize to the data center.

\subsubsection{Data Architecture}

The focus of this study is to provide a systematic guide to transform the conventional application into Big Data Analytics. It is called Big Data because it cannot be managed conventionally [15]. The characteristics of data called big data are:

Having huge volumes, Daily activity in the public health service requires special treatment and management to control. A scientist predicts in 2025 , total data in the world reach 181 Zettabytes [16]. The prediction user base of Sikda NG reaches more than 25.000 concurrent users on the daily basis. Hence big data is a right choice in preparing the vast volume of users activities.

Having significant data velocity, Data velocity refers to how fast data growth day by day. Managing data velocity cannot use a traditional way such buying more independent hardware and install it in the data center. Data velocity needs distributed system approach to make sure the flourishing data do not disturb the application service.

Having Data Variety, In the conventional database system using relational database management system (RDBMS), the data consist of data table and connecting among them and usually in the text format. On the other hand, in the Big Data, the data types more variative. The data can be a text, voice recorder, video, images, and so on. of course, the database management system would be more complicated than traditional. This software architecture should document activities in health care service such as medical record, lab document, Rontgen, lab result, and medical history.

In data architecture, there are several aspect should be implemented in Sikda New Generation to fulfill the targeted 120 architecture, the aspect are:

a) Direct database access: This approach only user who use mobile or web application directly to the application. The sum of the database will vary based on total microservices in Sikda NG. the database will directly store the data to data like and after that placed in the data warehouse.

b) API Connection: API connection is used to integration and interoperability data activities. Sikda NG provide health care data taxonomy as the standard code for health care data reference.

c) Local database: This database is a mirror database from the server. This database is valuable when the internet connection is unstable or geographically in a remote area. The system able to run in offline condition and automatically synchronize when the internet connection is detected.

\subsection{Technology Architecture}

Technology architecture is about infrastructure that support the business logic and information system. This section exhibit present and desirable condition of the public health service.

\subsubsection{Current technology Architecture}

The IT dept in MoH use on premise server to support the information technology activity at Ministry of health. Currently they have $1.900 \mathrm{Mbps}$ plus 400 idle bandwidth backup. They also own 669 servers and 208 server from other sub-department in Ministry of health. Lastly, IT department also have a backup an cloud storage, the detail information can be find in the table below.

Table 3. current infrastructure summary

\begin{tabular}{lll}
\hline No & Infrastructure & Note \\
\hline 1 & Bandwidth & Main Internet 1.900 Mbps \\
& & Backup bandwidth $400 \mathrm{Mbps}$ \\
2 & Hosting and Co-Location & 470 Subdomain \\
& & 669 Server (Physical and virtual) \\
& & 208 physical server from other \\
& & department \\
& & Hot Backup for ten critical applications \\
& Backup & Warm Backup for 20 applications \\
& & Cold Backup for IT departmentdoc and \\
& & 30 virtual server \\
\hline
\end{tabular}

\subsubsection{Future technology architecture}

In the technology architecture, we purpose cloud solution for managing Sikda NG because of the flexibility and answering digital challenges especially implementing advanced technology in Big Data. The previous study has shown the need of implementation the cloud in the healthcare domain research[19]. Figure 8 present cloud architecture that can be adopted for Sikda New Generation.

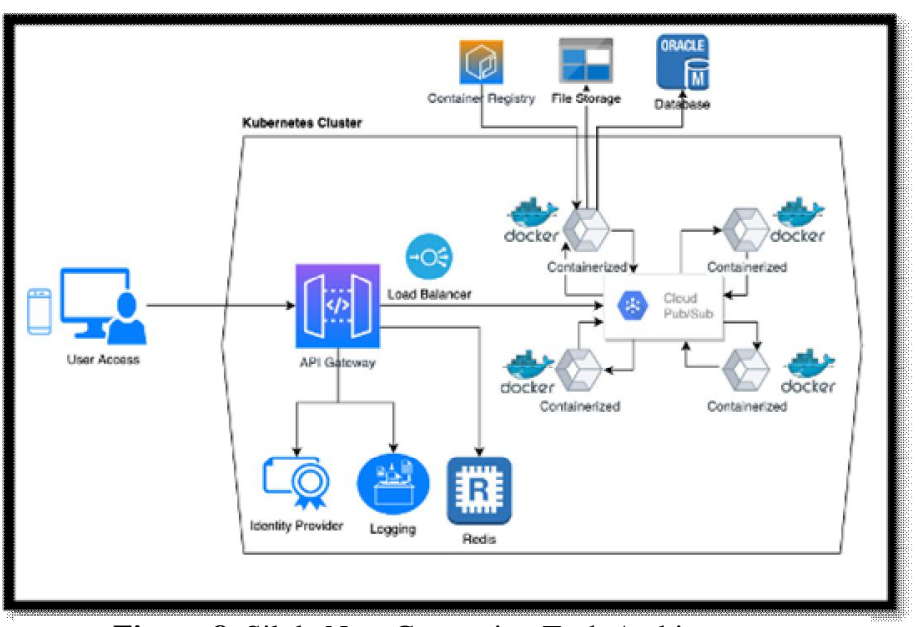

Figure 8. Sikda New Generation Tech Architecture 
The new architecture consist of a cloud environment that running dockers as container. The orchestration managed by load balancer under pubsub communication to make sure the availability using a minimum resources.

Ideally, government data should be store in the local region of data center. However, the flexibility, availability, and the security should be guarantee. While waiting the government build a local government data center, the cloud providers should be the option for now. Choosing the proper cloud provider based on what is needed and fit with the regulation of Indonesia related to data management. A quadrant leader Gartner of public cloud service can be an excellent reference to choose the high quality of service cloud provider[20]. Secondly, our recommendation using container technology as the baseline of system development and deployment. Container technology such as docker, hyper-v containers from Microsoft, RKT, podman could help each microservices defining its environment. Hence, the system can develop and run modularly without disturbing others.

\subsection{Implementation Government phase}

In this section, we draft a governance action list to help the IT department to implement Sikda NG successfully. Implementation governance is developed to align business processes and information technology. Technology is adopted to support business growth and innovation implemented in public health services. Below is the governance action list created after discussion with the executive in the Ministry of Health.

Executives Commitment, $\mathrm{MoH}$ is a vertical institution under the Minister of health. Moreover, $\mathrm{MoH}$ must release a new regulation and change the policies. The executive's commitment is becoming a powerful weapon to successfully implement new technology such as cloud systems, artificial intelligence, big data, and analytics.

Revise procurement regulation, Currently, hundreds of applications are running in the healthcare ecosystem in the Ministry of health, province health office, district health service, pharmacy industries, healthcare laboratories, hospitals, and many more. As a regulator in the health area, the Ministry of health, especially IT department can be the agent of change. IT department should prepare the information system and information technology roadmap for future development. Since the procurement cost is taken from the state budget, $\mathrm{MoH}$ could draft an approval procurement cost regulation in spending information systems and technology for $\mathrm{MoH}$ subordinates and departments.

Integration and interpretability regulation, Covid-19 diseases ameliorate social awareness related to personal and social health. At the same time, the awareness of information technology increase exponentially. Innovations and creativities always come up with collaboration in implementing information technologies. Thus, $\mathrm{MoH}$ should be able to create a standard of healthcare information system that can be integrated to filter integration requests and take care of the data, information system, and technology.

\section{CONCUSSION AND FURTHER WORK}

Managing health data and regulation is not an easy task. $\mathrm{MoH}$ has shown excellent service and responsiveness in managing health data and information. However, maintaining hundreds of applications meaning spending more energy, people, and the state budget. This study has unearthed the architecture for managing public health service from traditional conditions toward Big Data Architecture readiness. In the business architecture, the concern of multiple-input, redundancy data, and various systems should be eliminated. We analyze the public health regulations, ecosystems, and applications heterogeneity. Our proposal is only to use a single application to data input and then other applications acting as the users. After successfully implement Big Data and analytics, the desirable data and information may be requested directly from the data mart.

TOGAF ADM provides a valuable framework in the current business model and shows the transformation path in business, data, information system, infrastructure, and implementation governance to Big Data analytics readiness.

\section{REFERENCES}

[1] Kemenkes, "Grand design teknologi informasi Kementerian Kesehatan," Jakarta, 2012.

[2] Nila Farid Moeloek, "Grand design health Information System 2015-2019," 2015.

[3] E. Niemi and S. Pekkola, "The Benefits of Enterprise Architecture in Organizational Transformation," Bus. Inf. Syst. Eng., 2019, doi: 10.1007/s12599-019-00605-3.

[4] Aulia Azhar Abdurachman, "Penerapan Framework TOGAF dalam Perencanaan Strategis Sistem Informasi Studi Kasus pada Kementerian Pertanian," Binus University, 2019.

[5] M. Zahrudin, "Perencanaan Strategis Sistem Informasi pada Penyelenggaraan SIKN dan JIKN dengan Menggunakan Framework TOGAF," Bina Nusantara University, 2018.

[6] M. A. A. Hakim, "Perancangan Arsitektur Teknologi Informasi Untuk Mengotomatisasi Proses Bisnis Enterprise Dengan Menggunakan TOGAF ADM Studi Kasus PT Aero Systems Indonesia,” 2019.

[7] A. Haghighathoseini, H. Bobarshad, F. Saghafi, M. S. Rezaei, and N. Bagherzadeh, "Hospital enterprise Architecture Framework (Study of Iranian University Hospital Organization)," Int. J. Med. Inform., vol. 114, no. March, pp. 88-100, 2018, doi: 
Agung Laksono et al., International Journal of Emerging Trends in Engineering Research, 10(2), February 2022, $114-122$

10.1016/j.ijmedinf.2018.03.009.

[8] A. S. Girsang and A. Abimanyu, "Development of an Enterprise Architecture for Healthcare using TOGAF ADM," Emerg. Sci. J., vol. 5, no. 3, pp. 305-321, 2021, doi: 10.28991/esj-2021-01278.

[9] A. Kosasih, K. Angriawan, G. Wang, and N. Legowo, "Designing enterprise architecture for gasoline distribution monitoring system using IOT technology," Int. J. Adv. Trends Comput. Sci. Eng., vol. 9, no. 3, pp. 2642-2648, 2020, doi: 10.30534/ijatcse/2020/23932020.

[10] Florian Kurniadhi, "Perancangan Sistem Digital Loan Pada PT XYZ menggunakan framework Enterprise Architecture TOGAF," Bina Nusantara, 2020.

[11] The Open Group Architecture Framework, "The Open Group Standard - The TOGAF® Standard, Version 9.2," p. 532, 2018, [Online]. Available: https://firebrand.training/uk/pdf/learn/open-group/to gaf-standard.pdf.

[12] Kemenkes, "Peraturan Menteri Kesehatan Republik Indonesia Nomor 31 Tahun 2019 Tentang Sistem Informasi Puskesmas," Kementerian Kesehatan Republik Indonesia, vol. 1, no. 1. Jakarta, pp. 41-57, 2019.

[13] Kemenkes, "Peraturan Menteri Kesehatan Republik Indonesia Nomor 43 Tahun 2019 tentang Pusat Kesehatan Masyarakat," Jakarata, 2019.

[14] Kemenkes, "Data Puskesmas di Indonesia," 2021. https://databoks.katadata.co.id/datapublish/2020/01/ 12/berapa-jumlah-puskesmas-di-indonesia\# (accessed Jul. 24, 2021).

[15] D. B. S. Suresh Kumar, D. B. K. Kamesh, and S. Umar, "A study on big data and its importance," Int. J. Appl. Eng. Res., vol. 9, no. 20, pp. 7469-7479, 2014.

[16] Statista, "Volume of data/information created, captured, copied, and consumed worldwide from 2010 to 2025," 2021. https://www.statista.com/statistics/871513/worldwid e-data-created/ (accessed Jul. 25, 2021).

[17] J. Darmont, C. Favre, S. Loudcher, and C. Noûs, "Data lakes for digital humanities," ACM Int. Conf. Proceeding Ser., 2020, doi: 10.1145/3423603.3424004.

[18] Z. Doan, AnHai Halevy, Alon Ives, Principles of Data Intgration. Elsevier Science, 2014.

[19] Y. Masuda, S. Shirasak, S. Yamamoto, and T. Hardjono, "Architecture Board Practices in Adaptive Enterprise Architecture with Digital Platform: A Case of Global Healthcare Enterprise," Int. J. Enterp.
Inf. Syst., vol. 14, no. 1, pp. 1-20, 2018, doi: 10.4018/ijeis.2018010101.

[20] Gartner, "2020 Magic Quadrant for Cloud Infrastructure \& Platform Services," 2020. [Online]. Available:

https://pages.awscloud.com/GLOBAL-multi-DL-gar tner-mq-cips-2020-learn.html. 